Department of English, Faculty of Law and Business Studies Dr Lazar Vrkatić, Union University, Belgrade

\title{
TEACHING POETRY ONLINE: A LESSON PLAN
}

The aim of this paper is to offer literature teachers at the tertiary level of education in Serbia an innovative method of teaching poetry online to university students by providing applicable guidance for the suitable organization of online poetry classes. We endeavour to demonstrate and explore the use of various online activities designed to meet different objectives that will enhance students' understanding of the genre of poetry, trigger their motivation to study poetry, and change their perception of poetry from something perhaps too complex, inaccessible, and time-consuming to be properly analyzed and discussed to being still relevant and approachable in the digital age. For this purpose, we will use the poem "The Lady of Shalott" (1842) by Lord Alfred Tennyson, one of the most notable and prolific literary figures of one the most prosperous periods in the history of the British Empire - the Victorian Age.

Key words: distance learning, online teaching, 19 $9^{\text {th }}$-century English literature, online poetry course, online tools, Lady of Shalott

\section{Introduction}

Due to the rapid development of digital technologies and the overreaching influence of globalization, language programs at the tertiary level today offer a starting point for many different careers. Therefore, most language programs specify goals and competencies to be achieved during the course of study, two of the most prioritized being communicative competence and intercultural awareness, which prepare students for effective communication in a wide range of contexts and

milenanikolic86@yahoo.com 
situations (JurančićPetek, 2012; Krivokapić-Knežević\&Banjević, 2012; Sentov \& Wattles, 2020). Tertiary education institutions in Serbia and the Republic of Srpska are obliged to state theirgoals and competencies in the accreditation rules and standards. Developing intercultural awareness and critical thinking skills are essential aspects of mastering successful communication, especially in the context of the new millennium (Elmouhtarim, 2018: 332). To achieve such competencies, many English language programs in Serbia and the Republic of Srpska have attempted to integrate these skills into their academic courses aimed at developing language proficiency, linguistic knowledge, and understanding English literature, culture, and history.

As of March 2020, the COVID-19 pandemic has forced most colleges and universities in Europe to close and professors to shift their courses online. It has been a challenge for both teachers and students in every field, but in particular to those in the humanities (Flaherty, 2020). Before the pandemic, online courses and distance learning in general were rarely existent at universities in both Serbia and the Republic of Srpska. Accredited distance learning study programmes in Serbia are mostly in the field of IT, or in interdisciplinary studies. Very few exist inthe fields of social sciences, and none in the humanities. ${ }^{1}$ Distance learning programs often include a foreign language course (most often English) as a compulsory elective, but teachers and instructors in this discipline are almost invariably offered only basic technical training (i.e., how to use the tools on the online platform). Training in the specific methodology of distance learning teaching is not provided, leaving many teachers demotivated and overworked (Đukić-Mirzayantz, 2017: 45). A small number of Serbian researchers in this field (Mišićllić, Trajanović, and Domazet, 2007; Radić-Bojanić, 2012;Vukotić and Tanasijević, 2012;Đorđević and Radić-Bojanić, 2014; Tanasijević and Vukotić, 2014; Đukić-Mirzayantz, 2017; Gajić and Maenza, 2019) have addressed the challenges of creating and implementing online foreign language courses, as well as the attitudes and beliefs of foreign language teachers, but the effectiveness of distance language learning in Serbia is still a largely unexplored area (ĐukićMirzayantz, 2019: 133).Language and literature teachers, therefore, have

1 National Entity for Accreditation and Quality Assurance in Higher Education (NEAQA)

https://www.nat.rs/wp-content/uploads/2020/08/Ishodi-akreditacija-01.08.2020.pdf 
faced a considerable challenge in trying to transfer content that inherently requires live interactions and discussions to an online environment.

This paper discusses the challenges of teaching English literature in an online environment and offers a lesson plan that integrates critical thinking skills and intercultural awareness into an analysis of Tennyson's poem "The Lady of Shalott."

\section{The Importance of Critical Thinking and Intercultural Awareness in Literature Courses}

Critical thinking is defined as the ability to examine underlying assumptions or claims, or "distinguish bias from reason and fact from opinion" (Brookfield, 1987: 11-12). The development of critical thinking requires he ability to think logically and be informed about one's own culture. This, in turn, requires a flexible and modern educational system, based on facts, not opinions, and free of bias and prejudice. Only with such a system can learners be expected to become critical thinkers and continue to implement this skill themselves. Critical thinkingcan be learned and taught throughout one's life and is a skill that is never too late to learn'2.

Critical thinking teaches students to become accustomed to life-long learning and is best cultivated if applied in problem-solving activities, in decision-making processes, and in the posing of provocative questions aimed at training students in specific thinking skills such as metacognition, inference, analysis, hypothesizing, evaluation, etc. (King, 1994; Bean, 1996; Halpern, 1997; Epstein, 2003). Brookfield (1987: 26) identifies four "components" of critical thinking: identifying and challenging assumptions, challenging the importance of context, imagining and exploring alternatives, and developing reflective skepticism. As critical thinking is associated with the ability to properly evaluate and assess arguments, institutions of higher education should prioritize this skill and act as a key proponent for promoting and implementing its instruction. Questions that trigger and foster higher order thinking skills can be discussed and presented in an online environment in the form of the online discussions.

Higher education institutions have a crucial role to play in the development and promotion of critical thinking skills. Instead of viewing

2 World Learning (2018). What is critical thinking? In "Integrating Critical Thinking Skills into the Exploration of Culture in an EFL Setting" [Online course] 
these institutions as "factories of knowledge" (Debela\& Fang, 2008) and trying to cram as much information as possible into university courses, curriculum administrators and instructors should integrate critical thinking skills into the curriculum as one of the desired learning outcomes. In an increasingly globalized world, we are more than ever in a position to visit, study, or work within different cultures. Critical thinking skills are useful in learning about cultural groups different from our own, in establishing successful communication with them, and in avoiding misunderstandings and conflict. What is especially important is that in developing critical thinking, we also become aware of our own cultural values and assumptions (Bennet, 1998). These are usually so deeply embedded in our way of thinking that they seem like the only "right" or "normal" way of doing things. Educating and enabling learners to realize that their way of doing things is only one of many viable ones is an important step in developing critical thinking and intercultural competence. Incorporating other points of view into our reasoning is a valuable skill for every member of a culture and one which will become even more so going forward.

Critical thinking has been advocated by numerous scholars and educators as one of the essential skills that higher education institutions should teach in order to help students operate effectively within society and make responsible personal or business decisions (Stefanova, 2017; Facione, 2007; Willingham, 2007). Many authors have insisted that literary analysis is a particularly effective way to teach critical thinking skills, as they both involve understanding hidden meanings, separating facts from opinions, examining multiple viewpoints, and argumentation and reasoning (Bobkina and Dominguez, 2014; Facione, 2007; Lazere, 1987; Van, 2009; Yaqoob, 2011). Additionally, literary texts have been extolled as excellent means of teaching EFL students about culture and enhancing their intercultural awareness (Bobkina and Stefanova, 2016; Floris, 2004; Stefanova, 2017). Literary analysis helps develop students' ability to think critically and to explore and discuss social problems and cultural differences.

There are many scientific and professional articles that contain lesson plans based on the analysis of a particular literary text.An article by Bobkina and Stefanova (2016) proposes a series of activities based on Rudyard Kipling's poem "If"that aim to teach critical thinking skills based on the readers' response to the literary text.In addition to this, the authors Marías, 
Peñalver, and Lopa (2017) provide a list of different online activities on the Moodle platform designed to enhance students' understanding of the genre of poetry and motivate them to engage in its study. In a similar vein, we propose a lesson plan containing a series of activities focused on the poem "The Lady of Shalott." These activities are meant to inspire students to interact with the text and with other students in order to communicate their interpretation of thework, to discover hidden orimplied meanings, and to examinethenarrative from multiple points of view - in other words, to encourage critical thinking. In the context of Tennyson's poem, intercultural awareness involves in-depth discussion of the historical and cultural traits of the Victorian Era: political movements, class relations, the economic situation, the Industrial Revolution, gender and class inequality, and values and assumptions. The Victorian era marks a time of great economic growth, industrialization, the rise of the middle class and entrepreneurs, a severe gap between the rich and the poor, technological discovery, conflict between religion and technological progress, an extremely high rate of criminality and prostitution, rigid conventions and stereotypes reflected in proper behaviour, the concepts of women's chastity and purity, a tendency to assume that a social class provides a proper standard of value, etc. The teacher's role is to help students recognize and challenge the Victorian stereotypes that emerge in the poem (the oppressive environment, poor conditions of women, gender inequality) while enabling them to identify and reflect upon cultural references and relate them to the present time. Students should be encouraged to exchange opinions, challenge others' opinions in a respectful manner, and acknowledge multiple viewpoints on the same event, situation, or issue.

\section{3. $19^{\text {th }}$ Century English Literature in an online environment}

The $19^{\text {th }}$ Century English Literature course represents an indispensable part of an English studies curriculum. The course objectives include introducing students to major literary movements and authors in $19^{\text {th }}$ century Britain ${ }^{3}$. The historically turbulent $19^{\text {th }}$ century shaped British culture and identity in many ways and profoundly influenced literary genres and themes in English and world literature. It is therefore essential for students of English to be well-acquainted with the history and culture 
of this period. The learning objectives include gaining knowledge of major poets and prose writers and their literary works, as well as their influence and legacy, developing critical thinking skills by discussing literary works, and developing intercultural sensitivity by recognizing cultural values and assumptions inthe analyzed texts.

In addition to this, the teacher should anticipate the challenges that students are likely to face in interpreting and understanding the literary work, especially given that teaching literature in an online environment is still widely unexplored and unutilized terrain in both Serbia and the Republic of Srpska. Contemporarily,many literature teachers likely find themselves struggling to bridge the gap between "digital-native students", already equipped for and acclimatedto living in the digital era, and traditional and conventional approaches to teaching literaturethat have been practiced for generations, if not centuries (Škobo and DragičevićĐerić, 2019: 84-85). Too often both literature teachers and students are deficient in knowledge and experience in dealing with a wide range of possibilities that new technological advances offer, resulting in a severe lack of online tools, and their implementation in teaching literature. Many scholars have noted the pressing need for incorporating digital tools into teaching Victorian literature (Crompton, 2017; Fleming, 2017; Nichols, 2017; Nikolić, 2017; Swafford, 2017; Škobo and Dragičević-Đerić 2019, Śkobo 2020). Taking this into consideration, the incorporationof online tools (even if only a few) in teaching poetry online (in particular, teaching Tennyson's poem, which is rather lengthy and demanding) would likely present a particularly challenge endeavor, yet one that is also highly productive and rewarding, and, thus, worth undertaking. Students in this scenariowould be expected to become versed in clicking on and engaging various links, visiting several websites, doing online games and quizzes with a timer, joining live meetings, regularly commenting on their colleagues' posts, taking part in forum discussions, submitting homework assignments via social networks, listening to audio poems and songs, coping with hypertexts instead of printed material, and so on. In addition, the students would likely be challenged by the poetic language and figures of speech, as well as by the historical and cultural context within which the poem was created.

Having in mind the challenges that are likely to arise when it comes to students' virtual "encounter" with the poem, the teacher should develop 
a plan for addressing these issues. In order to overcome the anticipated hurdles, the teacher shouldprovide students with materials to read prior to the live classinstruct them to read the literary work in advance, and help them recognize figures of speech in the class itself by postingsuitable tasks and discussing historical and cultural references during the session.

The purpose of this paper is to offer literature teachers at the tertiary level of education an innovative method for teaching poetry online to university students by providing applicable guidance for the effective organization of online poetry classes. We endeavour to demonstrate and explore the use of various online activities designed to meet different objectives that will enhance students' understanding of the genre of poetry, trigger their motivation to study poetry, and change their perception of poetry as something too complex and time-consuming to be properly analyzed and discussed in the digital age (Appendix 1). For this purpose, we will use the poem "The Lady of Shalott" (1842) by Lord Alfred Tennyson, one of the most notable and prolific literary figures of perhaps the most prosperous period in the history of the British Empire - the Victorian Age.

As the course on $19^{\text {th }}$ Century English Literature is most commonly encountered during the students' second and/or the third year of the four-year-long study programme of English Language and Literature at many institutions in Serbia and the Republic of Srpska ${ }^{4}$, the online activities presented and explored in the following section are intended to be harmonized with the anticipated students' age and language level. The approximate age of the students is anticipated to be between 19 and 22 , whereas the language level varies from $\mathrm{B} 1$ to $\mathrm{B} 2+$. The envisioned length of the online poetry lesson is 60 minutes and the number of students participating between 5 and 15. The following lesson plan is designed for the purpose of synchronous teaching, as literature classes predominantly require immediate feedback from the teacher, the need for the additional clarification of certain concepts related to the content of the literary work

$4 \quad$ At the Faculty of Philology at Sinergija University in Bijeljina and the Faculty of Philology, University of Belgrade, Victorian Literature, an essential part of the course onEnglish Literature II and English Literature III, is mandatory and is taught to secondyear students. At the English Department of the Faculty of Law and Business Studies Dr Lazar Vrkatić in Novi Sad and Niš, English Literature of the 19th Century is taught to third-year students. Similarly, at the Faculty of Foreign Languages at Alfa University in Belgrade, there is a mandatory course on Victorian Literature and Culture taught to thirdyear students. 
that teachers too often overlook or simply consider redundant, a smooth two-way transition of information in real time, and live discussions that trigger critical thinking, which is by all means the ultimate goal literature teachers are striving forregarding the students' involvement and participation in literature classes.

\section{Lesson Plan Development}

Each lesson plan needs to indicatethe time needed for each activity and the lesson content presented through a description of the activity stages (a warm-up for introducing the topic to the class, elicitation aimed at testing the students' current knowledge on the topic, the presentation of the main topic, the use of controlled and free practice activities, review and follow up to assess whether students have grasped all the concepts taught). The teacher should anticipate with relative certainty what the students will do and how the teacher-student/student-student/ studentcontent interaction will proceed. Also, language focus should be concisely presented (the kind of language students will be using and practicing) together with the teacher's role (the key notions and concepts the teacher will be paying attention to). Moreover, the teacher should focus on the questions he/she will be asking the students in order to deepen their learning and understanding. The teacher will most likely be required to introduce the students to relevant materials and sources before the class and provide materials for anyfurther reading to completed after the class. Setting homework tasks and expectations and providing feedback are also crucial for lesson planning, so the teacher should particularly pay attention to these stages when writing a lesson plan.

As Tennyson's poem is largely inspired by the Arthurian legend, in particular the castle Camelot and the legendary Lancelot, one of the Knights of the Round Table and King Arthur's greatest companion, the teacher should make sure the students are familiar with the legend. One engaging wayof including the legend into the lesson planand refreshing the students' knowledge of the events concerning King Arthur and Camelot might be in the form of an online quiz set up as a five-minute warm-up activity. For the purpose of this lesson, we found an already existing online quiz on the websiteFun trivia https://www.funtrivia.com/playquiz/ quiz3016502288b78.html. However, the teacher might choose to create his or her own quiz via game-based learning platforms such as Kahoot! 
(https://kahoot.it/), Sporcle(https://www.sporcle.com/), or Quizziz (https:// quizizz.com/join). After doing the quiz, the students should then share their score with the rest of the class via online chat or video call (students turn on their microphones). A brief discussion should follow, in which students try to link the quiz content to the legend of the Lady of Shalott. At this point, the teacher should check the students'familiarity with the legend, their ability to understand the legend, and establish the links between the legend and Tennyson's poem, as well as assess the students' awareness of the historical context of the poem. The questions the teacher might ask at this stage in order to test students' prior knowledge and deepen their learning should focus on distinguishing history from legend, Arthurian legend, and Camelot, as the realm and a symbol of the Arthurian world, as well as on the ways in which Tennyson transforms and subverts the tradition. Moreover, the teacher mightinquire whether the students have watched any film based on the legend of King Arthur and his knights of the Round Table and/or suggest watching one of the film adaptations based on the legend (i.e., 1967's Camelot /https:/www.imdb.com/title/tt0061439/ based on the Broadway musical from a decade earlier - an epic that tells the story of the rise and fall of Arthur and Camelot framed around the love triangle between Arthur, Guinevere, and Lancelot; the 1981 epic adventure Excalibur starring Helen Mirren, Liam Neeson, and Nigel Terry that follows the sword of power from the hands of Uther Pendragon to the stone to Arthur's court/https://www.imdb.com/title/tt0082348/; 2004's King Arthur (https://www.imdb.com/title/tt0349683/) with Keira Knightley as Guinevere and Clive Owen as King Arthur, whichtakes a more "historical" approach to the tale of the King and his Round Table knights, setting them in a war against the invading Saxon forces; or 2017's King Arthur, Legend of the Sword - the latest major media take on King Arthur, presented as a medieval gangster who runs a brothel https://www.imdb.com/title/ tt1972591/). Links to the films shall be provided as additional material.

After warm up activity and discussion, the teacher is to present the main topic of the lesson in the form of a 5 to 10 minute-listening activity: the studentsare to listen to Part I and Part II of LoreenaMcKennitt's song (with lyrics) on YouTube (the link is provided https://www.youtube.com/ watch? $=80-\mathrm{kp} 6 \mathrm{RD} 194$ ), and turn on their microphones or use online chat in order to share their impressions about the song. At this stage, the teacher should focus on the students' receptive skills and their ability to determine 
the song's rhythm and rhyme scheme. The teacher should also inquire about the students' first impression of the song and the feeling it arouses in them, as well as about the tone of the song and its rhyming pattern.

The listening activity is to be followed by a ten-minute reading activity, withthe teacher providing the link to the poem via the Poetry Foundation website (https://www.poetryfoundation.org/poems/45360/thelady-of-shalott-1842) and the students reading aloud Part I and Part II of the poem. This should be followed by a vocabulary check, literary figures detection, and online discussion. The teacher shouldmake sure that the students understand the main ideas, themes, and events presented in Part I and Part II of the poem, assess the students' familiarity with the language of the poem, and help students determine the literary devices used in the first two parts of the poem. When it comes to analyzing the language details, the teacher might ask students to identify the words and expressions Tennyson uses to describe the Lady's feelings of isolation, loneliness, and melancholy. The students might also identify and analyze the adjectives, nouns, and verbs used by the author to describe the general atmosphere and mood of the poem. The vocabulary check could be organized via the use of Quizlet (https://quizlet.com/) by incorporating all the words the teacher anticipates the students may struggle with.In order to make the assignment aimed at literary figures detectionmore accessible for students, the teacher might provide the students with the link to the literary figures explanation video (https://study.com/academy/lesson/literary-devicesdefinition-examples-quiz.html) before the class. Finally, in order to deepen the students' learning and understanding of the main ideas and themes elaborated within Part I and Part II of the poem, the teacher might ask follow-up questions concerning the lady's curse and her magic web, the outside world's perception of the lady, the lady's inner world and feelings, the themes of isolation, sadness, and fear, the use of literary figures that contribute to the mode of the poem and the poem's theme, etc.

A similar procedure should be applied in covering Part III and Part IV of the poem. At this stage, the students should read the remaining parts of the poem silently. This is to be followed by a language focus and vocabulary check, literary figures detection, and online discussion (10-minute activity).Questions aimed at triggering critical thinking and deepening students' learning and understanding might focus on the description of Sir Lancelot, the possible reasons for the lady's leaving of 
the web, the general atmosphere and mood of the poem, and the possible functions of literary figures within the stanzas.

To enable an understanding of the poem in the context of 19thcentury art in Britain, students are to watch a five-minute YouTube video (https://youtu.be/ntokfw2OOdQ), exchange their impressions via online chat or video call, and develop a discussion aimed at establishing the links between $19^{\text {th }}$ and $21^{\text {st }}$-century art. At this stage, students should be prompted to provide examples of how art is reflected in the poem by referring to the text. The teacher should verify that the studentsare able to identify the main types of conflict (physical, emotional, moral, intellectual) present in Tennyson's poem, as well as recognize the main ideas regarding art and artists that would beapplicable to today's society.

In addition to this, the ideas concerning the temptations, inner conflicts, and challenges of artistsin the $19^{\text {th }}$ and $21^{\text {st }}$ century should be developed and addressed in accordance withrelevantliterary theories, such as Plato's theory of mimesis and Aristotle's defense, as well as Erich Auerbach's interpretation of mimesis as expressed in his book Mimesis: The Representation of Reality in Western Literature (1946). The summary of the main concepts of this book should be provided to studentsas part of the materials for further post-class reading (a link to the resource material should be provided or a downloadable pdf or word document attached https://sites.google.com/site/nmeictproject/home/plato-s-theoryof-mimesis-and-aristotle-s-defence ). One of the easiest ways of storing and sharing files is via Google Drive (the teacher creates the folder in Google Drive and gives students access to the folder).Resources for further reading which should help students do their homework might also include additional material related to Victorian art (http://www.visual-artscork.com/history-of-art/victorian.htm) or a reference to certain material in Victorian Web - one of the oldest academic and scholarly websites about the Victorian Age (i.e. a link to the section of the essay about English History of Art entitled "A Backward Journey through the 'Lady of Shallot': John William Waterhouse" http://www.victorianweb.org/painting/prb/ newman12.html\#jww).

Finally, the teacher should always bear in mind the ways in which students' higher order thinking skills can be activated when setting students' homework. Opening a discussion forum on a specific topic is one efficient option. Online platforms such as Moodle, Teams, Google Classroom, etc., 
allow teachers to create and use an online discussion board. However, those teachers that opt to not use any Learning Management System can download mobile applications for creating a discussion forum free of charge, such as Wix Mobile Application, Topic'it - Mobile Forum App, AC Forums App for Android, Tapatalk - 200,000+ Forums, etc., or simply use social networks (Facebook, Viber, Twitter, etc.) and blogs.

Questions intended to trigger critical thinking related to the poem "The Lady of Shalott" could focus on the ways in which art mirrors literature in the context of Tennyson's poem. This assignment should be set for homework, as should the time limit for its completion and delivery. The teacher might also post a list of theme-related questions the students could choose from. The students could then express their own opinion in a 250 to 300 -word essay and post it on the forum. If proceeding in such a direction, students should be required to comment on the posts of at least two of their colleagues. Moreover, the necessity of doing the assignments in due time should be stressed. The students should be also clearly notifiedof the obligatory nature of any assignments issued and their correspondingmanner and value of assessment (the students earn scores for each task). Moreover, it is of great importance that the teacher providestimely feedback to the students based on their answers and ensure such feedback be utilized in a visible and constructive way- the teacher should provide students with the opportunity to reflect on their errors and lead them to find ways to successfully overcome them infuture assignments. By incorporating feedback, greaterstudent learning ought to be achieved, especially as it has been evidenced that students asked to explain their misunderstanding demonstrate increases in their motivation for doing related tasks.

The method of assessment is particularly significant when it comes to proper planning of online literature class. The teacher should regularly combine peer and self-assessment and note specific stages and activities that he/she will use for assessment. The students must be made familiar with the grading system. Keeping regular class attendance and tracking students' activity on a regular basis (their participation in live discussions/online chat and successful completion of their assignments set for homework) are some of the most effective assessment methods for evaluating student learning and performance. Specific activities for assessment should include a controlledwriting activity in the form of a 
250-300 word-essay on specific topic submitted via e-mail or a free writing activity which assumes the use of a discussion forum (students write about the topic chosen, post it on the forum, and comment on the peers' posts), regular participation in live discussions or via online chat, and regular class attendance.In monitoring such submissions for authenticity, many educational institutions use programs such as Turnitin, an Internet-based plagiarism detection service, or M-Tutor. The teacher should make sure the students are familiar with the grading system and the distribution of points for each activity.

Finally, the teacher should identify and clearly point out the lesson objectives, that is, determine what students should be capable of the end of the online lesson. In respect to Tennyson's "Lady of Shalott," the students should be expected to understand the cultural references and sociohistorical context of the poem, as well as its main themes, key motives, and ideas. Furthermore, the students should be expected to make links between $19^{\text {th }}$ and $21^{\text {st }}$ century art and to think critically about the extent to which art mirrors literature and vice versa.

Another important aspect to consider in regard with the poem selected is the fact that it also invites different readings (i.e. feminist, psychoanalytical, postmodernist, etc.), which should be encouraged depending on the year of studies and focus of the course. Namely, the poem lends itself to analysis within the framework of gender studies, which is a particularly interesting and relevant segment for developing critical thinking, bearing in mind the fact that students like discussing this topic they can easily relate to. Also, the poem calls for psychoanalytical and autobiographical reading, which can also be discussed in the class - or at least mentioned.Finally, in regard with the students' level of education and the year of studies, they may be asked to comment on elements of metafiction, which is directed to the process of fictive composition and the act of undermining literary conventions, thus further exploring the relationship between fiction and reality.

\section{Conclusion}

With only a few accredited distance learning study programmesin the fields of social sciences and none in the humanities in both Serbia and the Republic of Srpska, it is clear that the concept of distance learning has been insufficiently developed at universities in Serbia and the Republic 
of Srpska and that more research needs to be done aimed at creating, developing, and implementing online teaching courses covering the fields of language and literature. By providing a model for an online poetry course, we have endeavoured to take the first step in the extensive process of building a solid basis for a smooth transition from the traditional, face-to-face method of teachingliteraturecomprising and demanding live discussions and close student-teacher interactions, to a more modern approach that takes place in a virtual environment.

The aforementioned model for an online poetry course has been carefully designed to meet the needs of literature courses at both secondary and tertiary level of education, as it combines various types of synchronous and asynchronous learning.Our exploring and presenting of the use of various online activities based on the 19th-century English literature that can be easily modified and upgraded to meet different objectivesshould enhance students' understanding of the genre of poetry, boost their motivation to study poetry, and change their perception of poetry as something too complex and time-consuming to be properly analyzed and discussed in the digital age.The proposed lesson plan with the combination of presented methods and activities is predominantly aimed at developingstudents' critical thinking by focusing on the most effective means of triggering discussion regardless of the type of learning environment (real or virtual). Due to the fact that this paper offers the variety of activities and methods the teachers may choose from and adapt to in order to meet the specific needs of their classes, it can be deduced that most of the activities presented may be successfully applied to online, traditional and blended (hybrid or mixed-mode) courses.

The 21 st- century students are digital natives who are prone to use modern technologies at a daily level. Therefore, this research points to some of the advantages of online teaching of literature courses such as triggering students' motivation by referring to the most modern multimedia resources, particularly those designed to meet the needs of literary courses. Also, this type of teaching is more student-centred, as it usually requires more self-independent work done by the student. The students are expected to conduct their own research, which can be more engaging as they may refer to various game-based platforms and the most recent applications that can make their learning process less tense. Moreover, the studentstudent interaction is enhanced by means of forum discussions and active 
participation in online quizzes, where the students can compete with each other or work together in order to achieve the higher score.

However, this type of teaching literature brings in mind possible setbacks that may arise. First of all, we should take into consideration the fact that not all students (and teachers) are supportive of any kind of online teaching whatsoever, therefore, online teaching literature course may be offered as an alternative to traditional - face-to-face - teaching literature to those students who are not able to attend the lectures in person for specific reasons (job, parallel studies, location, etc.), or those who just feel more comfortable with this type of teaching. Also, with this type of teaching, non-verbal teacherstudent and student-student communication is narrowed, which may be a very significant setback when it comes to foreign language learning.

Finally, we reiterate the importance ofintroducing more modern approaches towards graduallydeveloping and encouraging the process of critical thinking in an online environment as well as emphasizethe need for innovative, "digitalized" ways of tackling issues of socio-historical and cultural context in realizing successful online literature course creation and implementation. By providing a table with the list of online activities particularly designed to meet the needs of online literature classes and presenting a detailed procedure for their introduction and application supported by a variety of external links and multimedia content, we hope to have made at least a moderate contribution to the significant challengeofcreating and implementingquality online literature teaching at the tertiary level of education.in both Serbia and the Republic of Srpska.As regarding the online poetry courses in Serbia and the Republic of Srpska, the countries where the concept of distance learning has not been sufficiently explored and developed, particularly in the field of humanities, we hope our contribution would serve as a proper reference guideand an efficient alternative to face-to-face teaching to literature and foreign language teachers at English Departments of the Faculty of Philology at Sinergija University in Bijeljina and the Faculty of Law and Business Studies Dr Lazar Vrkatić, as well as to many literature and (foreign) language teachers who want (or need) to(partially or entirely) transfer the content of their lectures to virtual learning environment without neglecting the importance of a social factor in teaching literature.In regard with the aforementioned, this paper invites further research into teaching literature online and opens further questions regarding its advantages and disadvantages. 


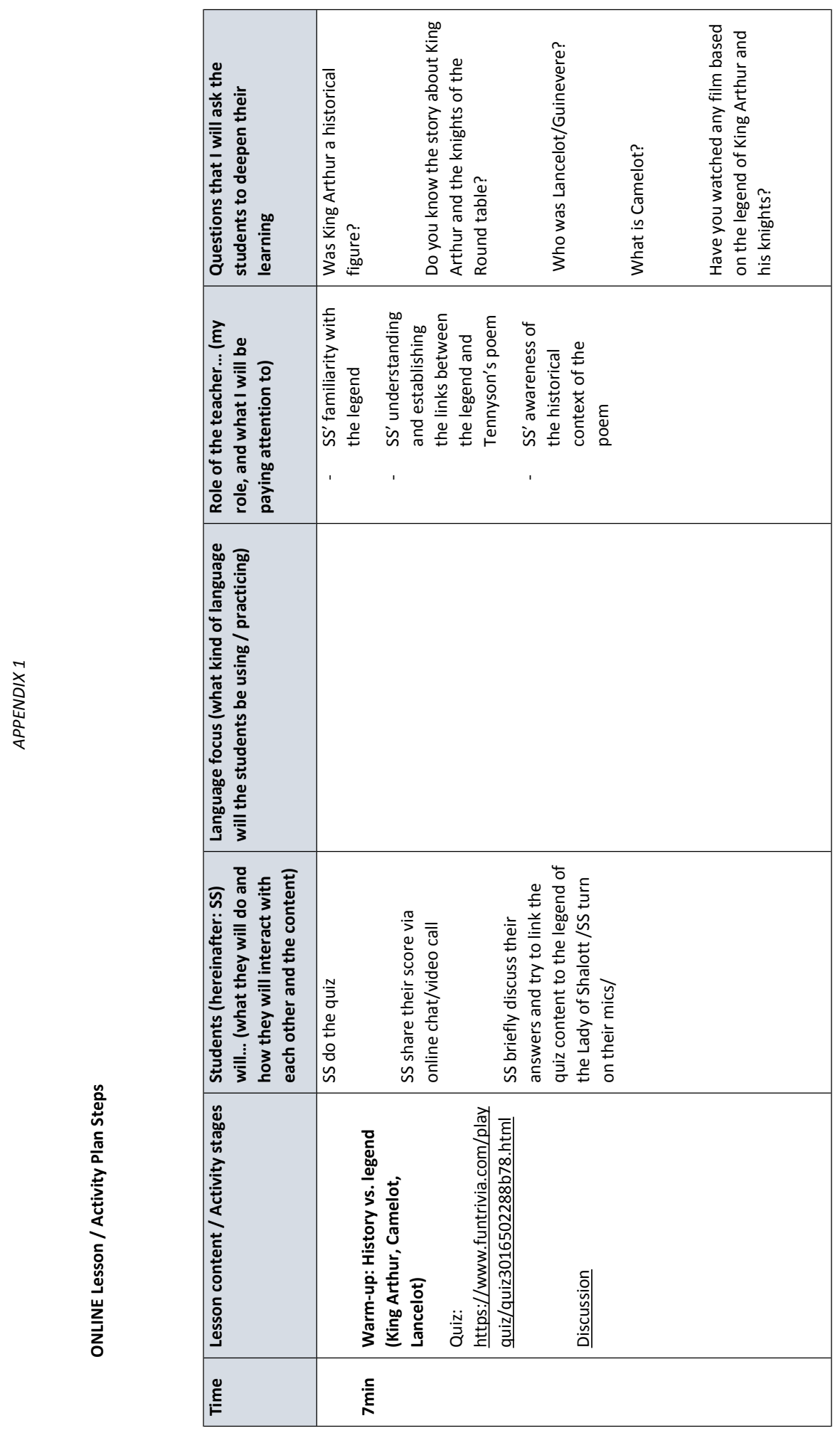




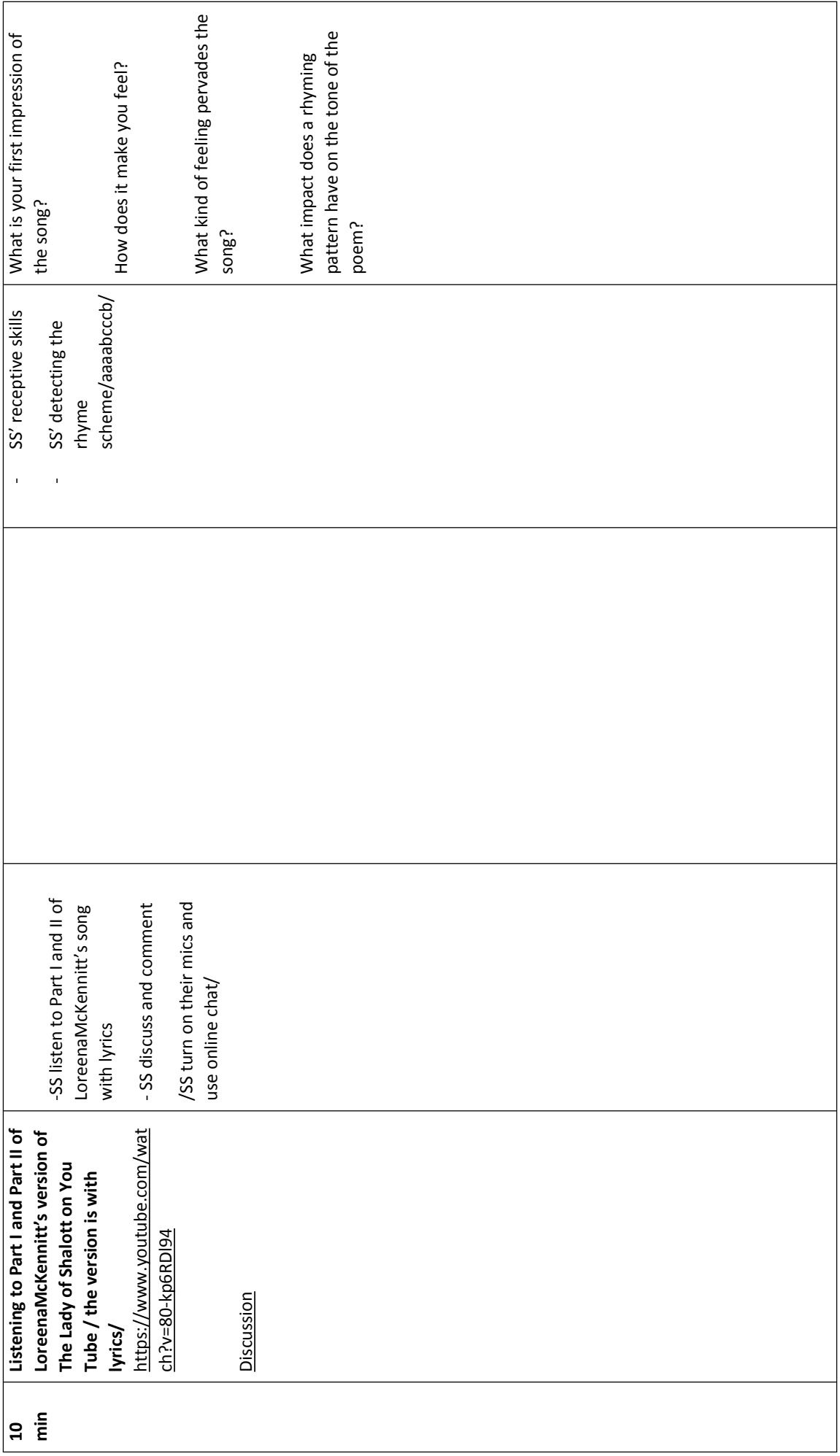




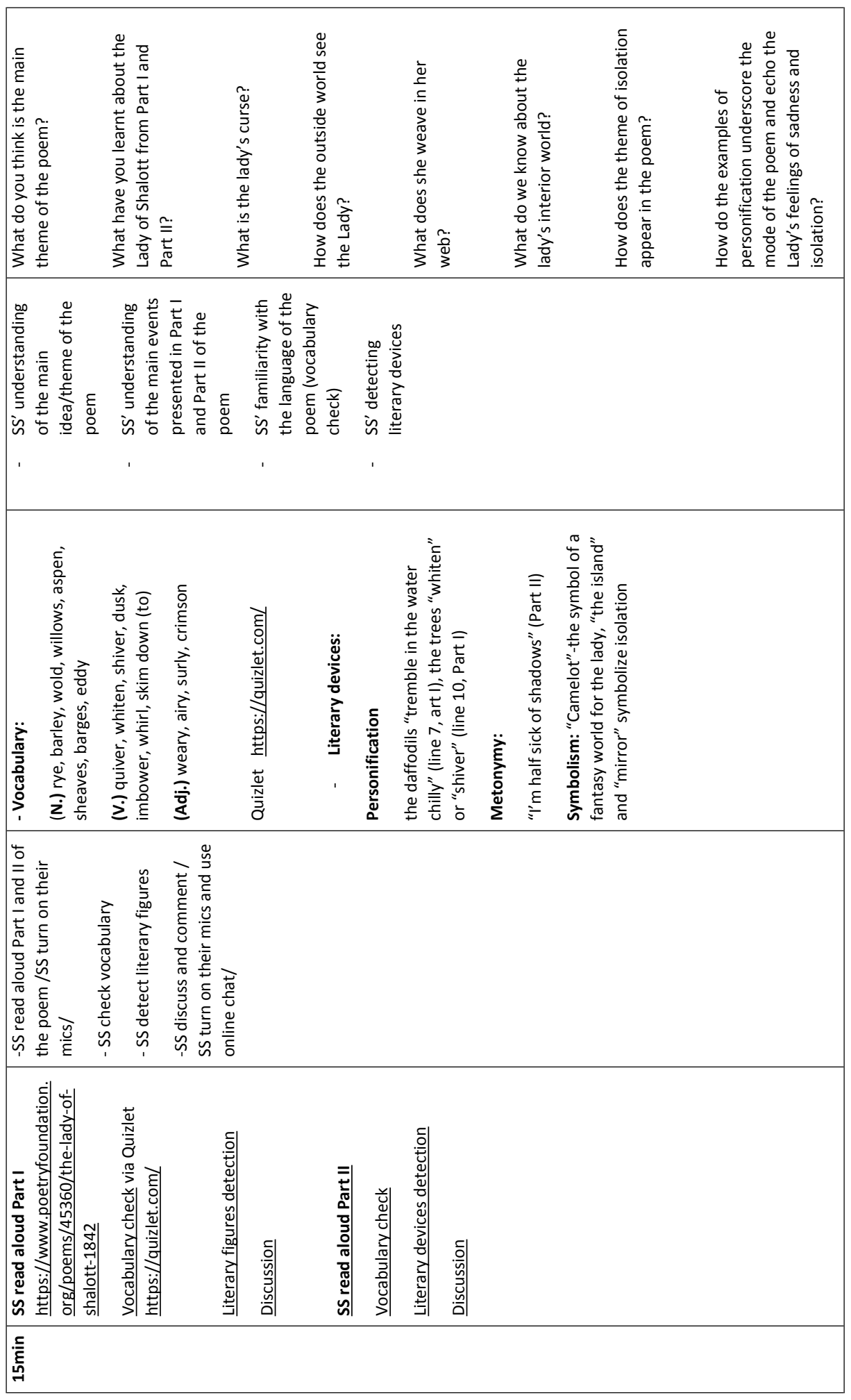




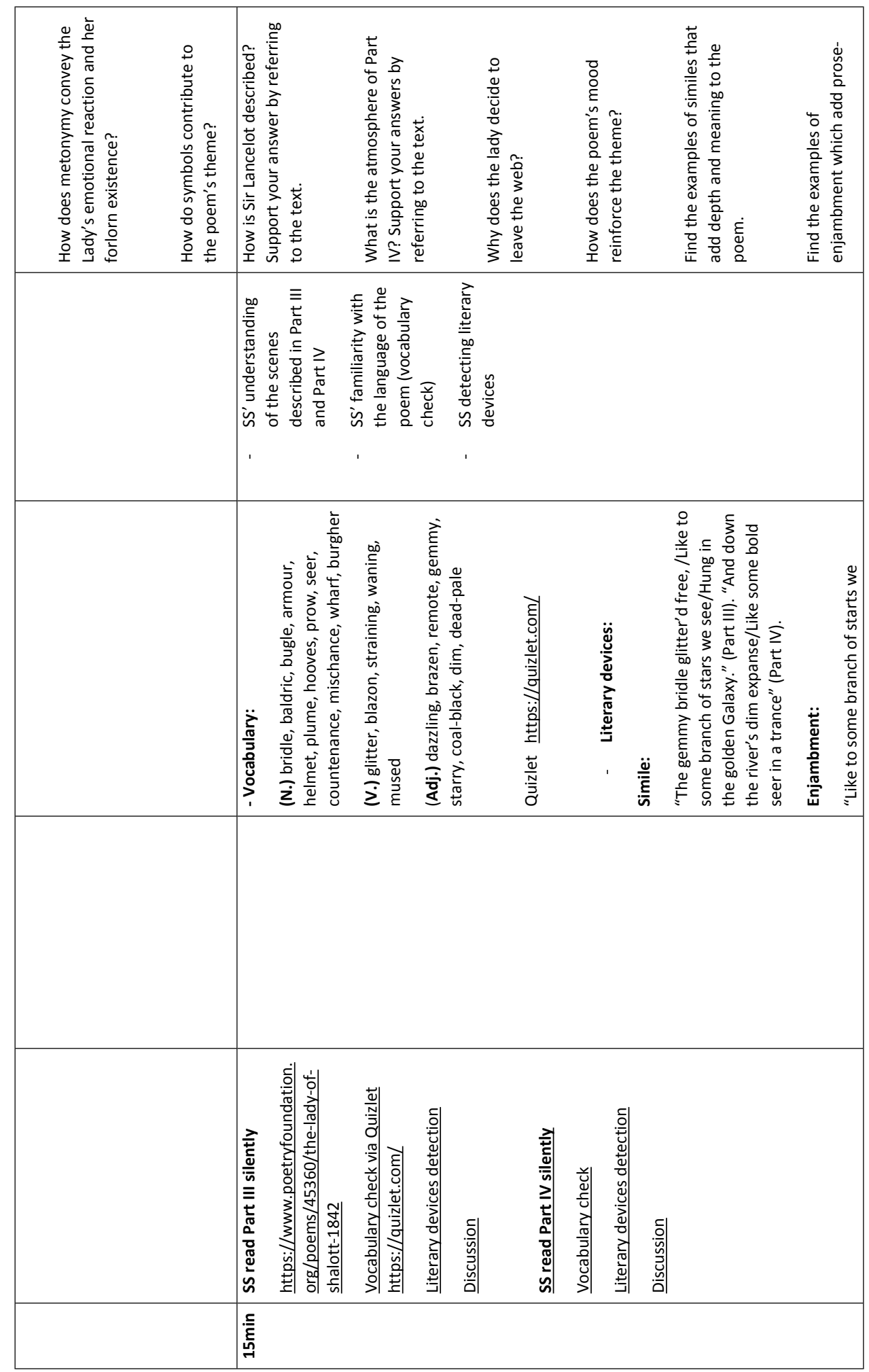




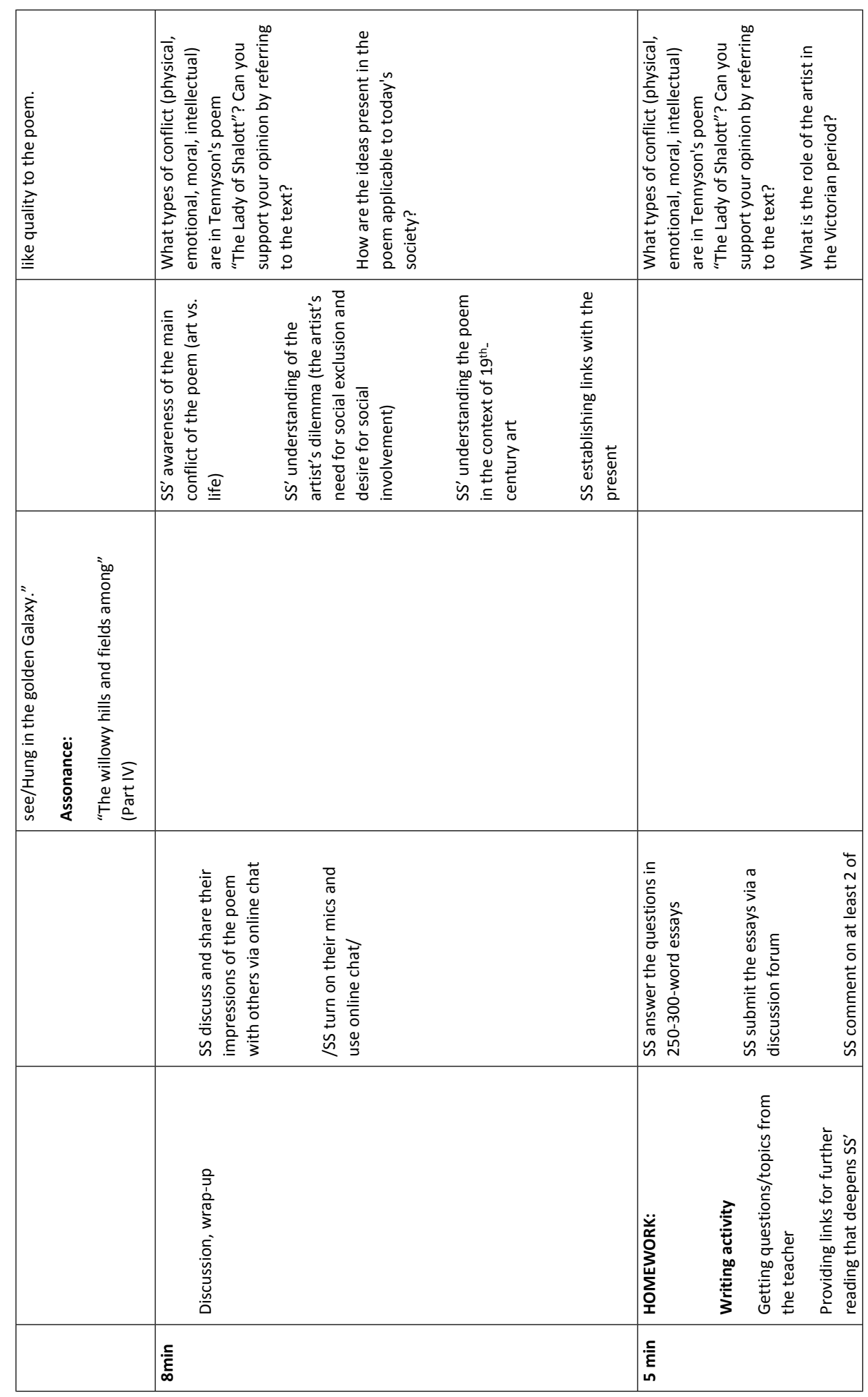




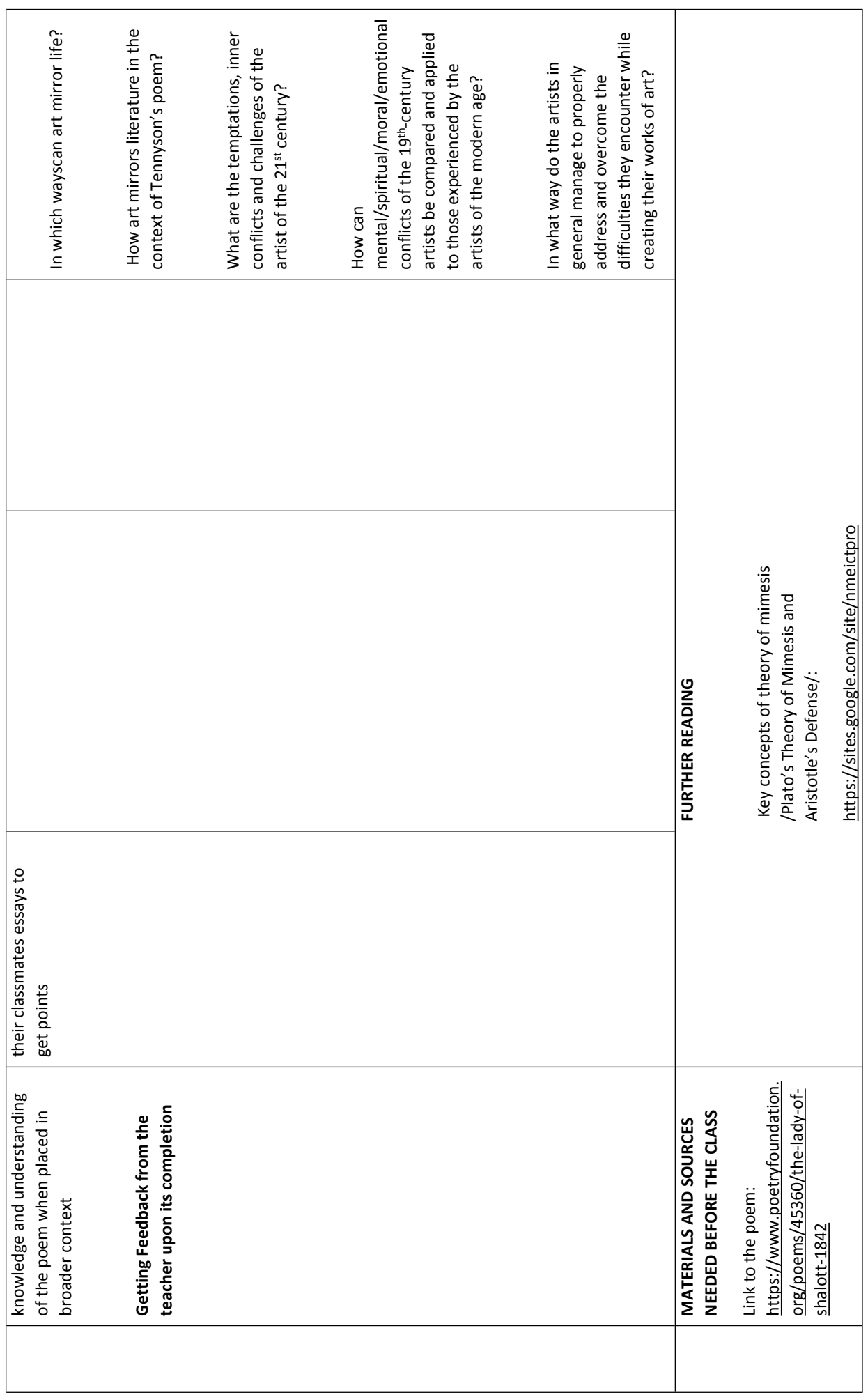




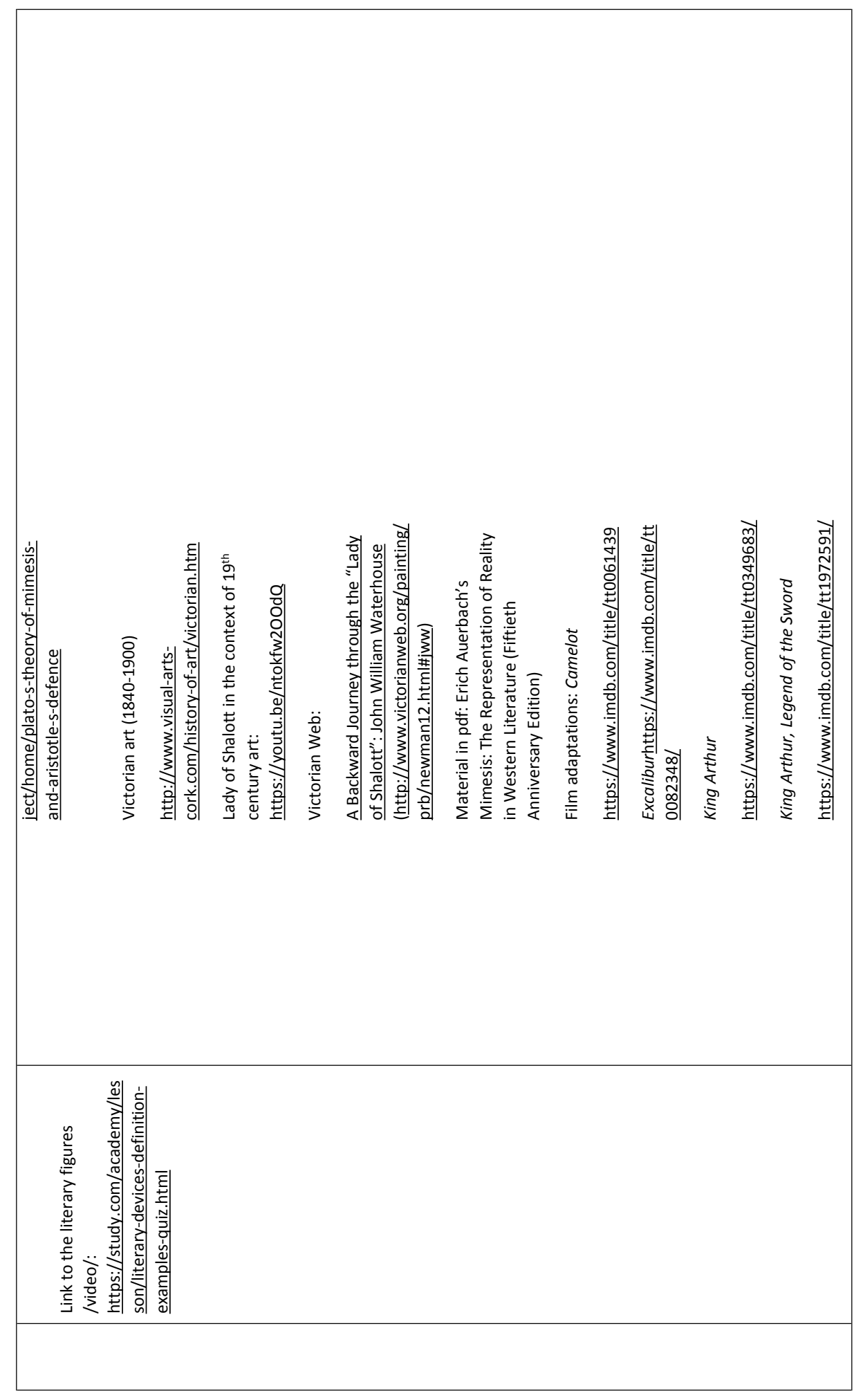




\section{REFERENCES}

Bean, J. C. (1996). Engaging ideas: The Professor's Guide to Integrating Writing, Critical Thinking \&Active Learning in the Classroom. San Francisco: Jossey-Bass.

Bobkina, J.\&Dominguez Romero, E. (2014). The use of literature and literary texts in the EFL classroom: Between consensus and controversy. International Journal of Applied Linguistics \& English Literature, 3(2), 248-260.

Bobkina, J. \&Stefanova, S. (2016). Literature and critical literacy pedagogy in the EFL classroom: Towards a model of teaching critical thinking skills. Studies in Second Language Learning and Teaching, 6 (4),677-696.

Brookfield, S.(1987). Developing critical thinkers: challenging adults to explore alternative ways of thinking and acting. San Francisco: Jossey-Bass.

Crompton, C. (2017). Teaching about and through computing: Victorian record keeping, data management, and the class edition. In J.Cadwallader\& L.W. Mazzeno (Eds.), Teaching Victorian Literature in the Twenty-First Century: A Guide to Pedagogy (pp. 211-226). USA: Palgrave MacMillan

Epstein, R. L. (2003). The Pocket Guide to Critical Thinking. (2nd ed.) Toronto, Ontario: Wadsworth.

Flaherty, C. (2020). 'As Human as Possible.' Inside Higher Education [online]. Retrieved from: https://www.insidehighered.com/news/2020/03/16/ suddenly-trying-teach-humanities-courses-online [11/08/2020]

Fleming, P. C. (2017). The Office is One Thing, and Private Life is Another. In J. Cadwallader\& L.W. Mazzeno (Eds.), Teaching Victorian Literature in the Twenty-First Century: A Guide to Pedagogy (pp. 197-210). USA: Palgrave MacMillan.

Halpern, D. F. (1997). Critical Thinking across the Curriculum: A Brief Edition of Thought and Knowledge. Lawrence Erlbaum Associates Publishers.

King, A.(1994). Inquiry as a tool in critical thinking. Changing college classrooms: New teaching and learning strategies for an increasingly complex world. $13-38$.

Lazere, D. (1987). Critical thinking in college English studies, ERIC Digest, Retrieved from http://www.eric.ed.gov/ERICWebPortal/contentdelivery/ servlet/ERICServlet?accno=ED284275.

Marías, C., Peñalver, E. A., \& Lopa, A. P. (2017). Teaching Poetry Through Songs in a Virtual Environment: From Students' Reluctance to Their Acquiescence. In M. L. Carrió-Pastor (Ed.), Teaching Language and Teaching Literature in Virtual Environments (pp. 255-276). Singapore: Springer 
Nichols, A. (2017). Ecocritical and Environmental Approaches: Teaching Victorian Poets and Novelists in the Age of the Internet. In J. Cadwallader\& L.W. Mazzeno (Eds.), Teaching Victorian Literature in the Twenty-First Century: A Guide to Pedagogy (pp. 315-328). USA: Palgrave MacMillan

Nikolić, M. (2017). The use of audio and video recordings in English Language teaching, XVIII International Scientific Conference - Sinergija 2017, Sinergija University, Bijeljina, Republic of Srpska, 120-124. doi: 10.7251/ ZRSNG1708120N

Sivasubramaniam, S. (2006). Promoting the prevalence of literature in the practice of foreign and second language education: issues and insights. The Asian EFL Journal Quarterly, 8(4), 254-273.

Stefanova, S., Bobkina, J., \&Sanchez-Verdejo Perez, F. J. (2017). The Effectiveness of Teaching Critical Thinking Skills through Literature in EFL Context: A Case Study in Spain. International Journal of Applied Linguistics \& English Literature ISSN 2200-3592 (Print), ISSN 2200-3452 (Online), 6 (6), November 2017 doi:10.7575/aiac.ijalel.v.6n.6p.252

Swafford, J. (2017). Virtually London: Literature and Laptops. In J. Cadwallader\& L.W. Mazzeno (Eds.), Teaching Victorian Literature in the Twenty-First Century: A Guide to Pedagogy (pp. 227-238). USA: Palgrave MacMillan

Tanasijević, M., Vukotić, A. (2014). The challenges of teaching ESP in traditional and virtual classrooms in Serbia at the academic level. In Z. Paunović (Ed.), English Language and Literature Studies: Embracing Edges. University of Belgrade: Faculty of Philology, 299-308.

Van, T. T. M. (2009). The relevance of literary analysis to teaching literature in the EFL classroom, English Teaching Forum, 3, 2-9.

Vukotić, A., Tanasijević, M. (2012). Forms of communication in online English courses: making the most of new technologies in higher education. In V. Polovina (Ed.), Applied linguistics, 13. Novi Sad: Applied Linguistics Association of Serbia, 7-16.

Willingham, D. T. (2007). Critical Thinking. American Educator, Summer 2007, $8-18$.

Yaqoob, M. (2011). Reader and text: Literary theory and teaching of literature in the twenty first century. International Conference on Languages, Literature and Linguistics IPEDR, 26, 511-515.

Škobo, M. \&Đerić-Dragičević, B.(2019). Teaching English Literature in the Digital Era. In: M. Stanišić (Ed.), Sinergija 2019 - XX International Scientific Conference, 20(5). Bijeljina, Republic of Srpska: Sinergija University, 84-89. doi: 10.7251/ZRSNG1901084S

Škobo, M. (2020). Modern Technologies in Teaching Literature. Paper presented at Sinteza 2020 - International Scientific Conference on Information 
Technology and Data Related Research, Belgrade: Singidunum University, 96-92. doi:10.15308/Sinteza-2020-86-92

Đukić Mirzayantz, M. (2017). The attitudes and experiences of foreign language teachers engaged in distance study programs in Serbia. The Online Journal of Distance Education and e-Learning, 5 (4), 36-46.

Đukić Mirzayantz, M. (2019). The effectiveness of learning German on Moodle. Inovacije u nastavi, XXXII, 2019/3, 130-150. doi: 10.5937/ inovacije $1903130 \mathrm{D}$

\title{
Milena Škobo
}

Ana Sentov

\section{PODUČAVANJE POEZIJE ONLAJN: PLAN ČASA}

\begin{abstract}
Sažetak
Cilj ovog rada je da ponudi nastavnicimaiprofesorima književnosti na tercijarnom obrazovnom nivou inovativan način podučavanja poezije, a koji podrazumeva podučavanje poezije u virtuelnom okruženju, uz pružanje konkretnih smernica u vezi sa samim načinom organizovanja nastave ovakve vrste. U radu će biti istražene i predložene različite onlajn aktivnosti koje se mogu koristiti kako bi nastavnici dobro organizovali onlajn čas na kome se obrađuje poezija. Ukoliko se pravilno primene, ove aktivnosti mogu da utiču na povećanje motivacije, kako kod nastavnika, tako i kod studenata - nastavnika da predaju, a studenata da čitaju, analiziraju i tumače poeziju. Rad sadrži plan časa i zadatke za analizu jednog poetskog dela na primeru pesme jednog od najpoznatijih I najznačajnijih pesnika viktorijanskog doba u XIX veku u Engleskoj, lorda Alfreda Tenisona, „Gospa od Šalota" (1842).
\end{abstract}

Ključne reči: učenje na daljinu, nastava na daljinu, Engleska književnost 19. veka, onlajn čas poezije, onlajn alati, „Gospa od Šalota”. 